\title{
Triplectides Kolenati (Trichoptera: Leptoceridae) from Brazil: A new species, new records and an identification key
}

\author{
Gleison Robson DESIDÉRIO ${ }^{1, *}$, Ana Maria PES ${ }^{2}$, \\ Patrik BARCELOS-SILVA ${ }^{3} \&$ Neusa HAMADA ${ }^{4}$ \\ 1,2,3,4 Instituto Nacional de Pesquisas da Amazônia (INPA), \\ Coordenação de Pós-Graduação (COPOG), Divisão do Curso em Entomologia (DiEnt), \\ Coordenação de Biodiversidade (CoBio), Manaus, Amazonas, Brazil. \\ *Corresponding author: gleysonbio@gmail.com \\ 2E-mail: anampes@gmail.com \\ ${ }_{3}^{3}$ E-mail: patrikbarcelos@gmail.com \\ ㄹE-mail:neusaha@gmail.com \\ ${ }^{1}$ urn:1sid:zoobank.org:author:63EE23DE-6125-4167-A3AA-27E2A9829283 \\ ${ }^{2}$ urn:1sid:zoobank.org:author:03D29AFD-A7EE-49DA-9740-7FA0F34932AF \\ ${ }^{3}$ urn:1sid:zoobank.org:author:BFE5C5B5-97A2-4CBB-8133-9737579F12D2 \\ ${ }^{4}$ urn:Isid:zoobank.org:author:0D02F36C-6B09-423C-95A6-6179E9808CD5
}

\begin{abstract}
The long-horned caddisfly genus Triplectides Kolenati, 1859 is the most species-rich within Triplectidinae, comprising about 90 species. Eight species have been recorded so far in Brazil, mainly distributed in the Southeast Region, and only one species has been recorded from the North Region. In this paper a new species of Triplectides is described and illustrated, Triplectides nessimiani Desidério \& Pes sp. nov., based on adult males from Serra do Aracá, Amazonas, Brazil. We also provide the first record for Brazil of T. neblinus Holzenthal, 1988 and T. nevadus Holzenthal, 1988. In addition, an updated identification key to Triplectides species with occurrence in Brazil is presented.
\end{abstract}

Keywords. Aquatic insects, Triplectidinae, long-horned caddisflies, Neotropical, Amazon.

Desidério G.R., Pes A.M., Barcelos-Silva P. \& Hamada N. 2020. Triplectides Kolenati (Trichoptera: Leptoceridae) from Brazil: A new species, new records and an identification key. European Journal of Taxonomy 677: 1-11. https://doi.org/10.5852/ejt.2020.677

\section{Introduction}

Leptoceridae Leach, 1815, or long-horned caddisflies, is one of the three largest trichopteran families. Four subfamilies are currently recognized: Leptorussinae Morse, 1981, Grumichellinae Morse, 1981, Leptocerinae, and Triplectidinae Ulmer, 1906 (Malm \& Johanson 2011), of which the latter three occur in the Neotropical Region (Holzenthal \& Calor 2017). 
Triplectides Kolenati, 1859, with about 90 species worldwide, is the most species-rich genus within Triplectidinae (Morse 2018). The genus is characterized in the adult stage by an apically broad discoidal cell that usually extends posteriorly and a thyridial cell two or three times as long as the discoidal cell in the forewing, and male inferior appendages with mesal and basoventral processes or lobes (Morse \& Neboiss 1982; Holzenthal 1988). Triplectides larvae build cases of a hollowed-out twig or from the discarded case of another trichopteran larva. Larvae of this genus are shredders and inhabit pool areas in small streams (Holzenthal \& Calor 2017).

The genus occurs in Central and South America, Southern-East Asia and Oceania. Its highest diversity occurs in the Australian Region, with 15 species recorded from New Caledonia and 25 from Australia (Malm \& Johanson 2008). In the Neotropical Region there are 17 species described, distributed from southern Mexico to southern Chile (Holzenthal \& Calor 2017; Desidério et al. 2017). So far, eight species have been recorded from Brazil: T. cipo Henriques-Oliveira \& Dumas, 2015, T. egleri Sattler, 1963, T. gracilis (Burmeister, 1839), T. itatiaia Dumas \& Nessimian, 2010, T. maranhensis Desidério, Barcelos-Silva \& Pes, 2017, T. misionensis Holzenthal, 1988, T. neotropicus Holzenthal, 1988 and T. ultimus Holzenthal, 1988 (Santos et al. 2019).

In this study, we describe and illustrate a new species of Triplectides based on adult males from Serra do Aracá, Amazonas state, Brazil. We also provide the first record for Brazil of T. neblinus Holzenthal, 1988 and T. nevadus Holzenthal, 1988. In addition, an updated identification key to species of Triplectides with occurrence in Brazil is presented.

\section{Material and methods}

Specimens were collected with Malaise traps (Gressit \& Gressit 1962), Pennsylvania light traps (Frost 1957 ) and Suspended traps (Rafael \& Gorayeb 1982). All collected specimens were preserved in $80 \%$ ethanol. In order to observe male genital structures, the abdomen was removed and cleared using hot $10 \% \mathrm{KOH}$ as detailed by Blahnik \& Holzenthal (2004). After clearing, the abdomen was examined with a Leica EZ4 stereo microscope; it was then stored in $80 \%$ ethanol in a plastic microvial, together with the remainder of the respective specimen.

Photographs were obtained using a Leica DMC4500 video camera attached to a Leica M205A stereo microscope using an LED illumination dome. Stacks of images of each structure were produced at different focal distances and then combined automatically into a single image with a greater depth of field using Helicon Focus ${ }^{\circledR}$ (version 6.7.1 Pro) stacking software. Stacked images of the genitalia were used as templates in Adobe Illustrator ${ }^{\circledR}$ to create vector graphic illustrations. Photographs and drawings were assembled into plates using Adobe Photoshop ${ }^{\circledR}$.

The morphological terminology used for male genitalia follows that of Holzenthal (1988). The map showing the geographical distribution of the species was created using QGis ver. 2.18.10 free software.

The types and all other examined specimens are deposited at the Invertebrate Collection of the Instituto Nacional de Pesquisas da Amazônia (INPA), Manaus, Amazonas, Brazil.

\section{Abbreviations of genital structures:}

ap. lo. = apicodorsal lobe

bv. lo. = basoventral lobe

me. lo. $=$ mesal lobe

ph. bs. = phallobase

ph. sc. $=$ phallotremal sclerite 
DESIDÉRIO G.R. et al., New species, records and a key of Triplectides from Brazil.

pr. ap. $=$ preanal appendages

$2^{\text {nd }}$ art. $=$ second article

\section{Institutional abbreviations}

INPA $=$ Instituto Nacional de Pesquisas da Amazônia, Manaus, Amazonas, Brazil

$\mathrm{NMNH}=$ National Museum of Natural History, Washington, DC, USA

\section{Results}

Class Insecta Linnaeus, 1758

Order Trichoptera Kirby, 1813

Suborder Integripalpia Martynov, 1924

Superfamily Leptoceroidea Leach, 1815

Family Leptoceridae Leach, 1815

Subfamily Triplectidinae Ulmer, 1906

Genus Triplectides Kolenati, 1859

Triplectides nessimiani Desidério \& Pes sp. nov.

urn:1sid:zoobank.org:act:0B5D5E41-9729-47F5-8108-8CAD58114588

Figs $1-3$

\section{Diagnosis}

The male of Triplectides nessimiani sp. nov. is similar to that of T. ultimus by fork I in the hindwing having a very short petiole and both having a short, subtriangular mesal lobe on the inferior appendage. However, in $T$. nessimiani sp. nov. the mesal lobe has a slightly acute lateral projection and 5-7 stout ventral setae in the middle region, whereas T. ultimus has bifid lateral projection and three stout ventral setae. Furthermore, the new species can easily be distinguished by the preanal appendages, which are digitate with apices rounded (slender with apices pointed in T. ultimus), tergum $\mathrm{X}$ with apex obliquely truncated (rounded in T. ultimus) and phallotremal sclerite well developed, subpentagonal-shaped in dorsal view (simple in T. ultimus).

\section{Etymology}

The new species is named in honor of Prof. Dr. Jorge Luiz Nessimian (Universidade Federal do Rio de Janeiro, Brazil) who helped collect the type specimens and in recognition of his contributions to the study of the Neotropical caddisflies.

\section{Material examined}

\section{Holotype}

BRAZIL - O; Amazonas, Barcelos, Parque Estadual Serra do Aracá, Igarapé da Anta (\#S05); 0054'38.70" N, 6325'54.70" W; alt. 1130 m; 26 Jul.-2 Aug. 2009; N. Ferreira Jr, J.L. Nessimain, F.F. Salles, A.P.M. dos Santos, U.G. Neiss and J.O. da Silva leg.; Malaise trap; INPA-TRI 000014.

\section{Paratype}

BRAZIL - 1 đं; Amazonas, Barcelos, Parque Estadual Serra do Aracá, Igarapé de $1^{\circ}$ ordem (\#S03); 0054'22.03" N, 6327'33.23" W; alt. 1110 m; 23 Jul.-1 Aug. 2009; J.O. Silva, J.L. Nessimian and U.G. Neiss leg.; suspended trap; INPA-TRI 000015. 

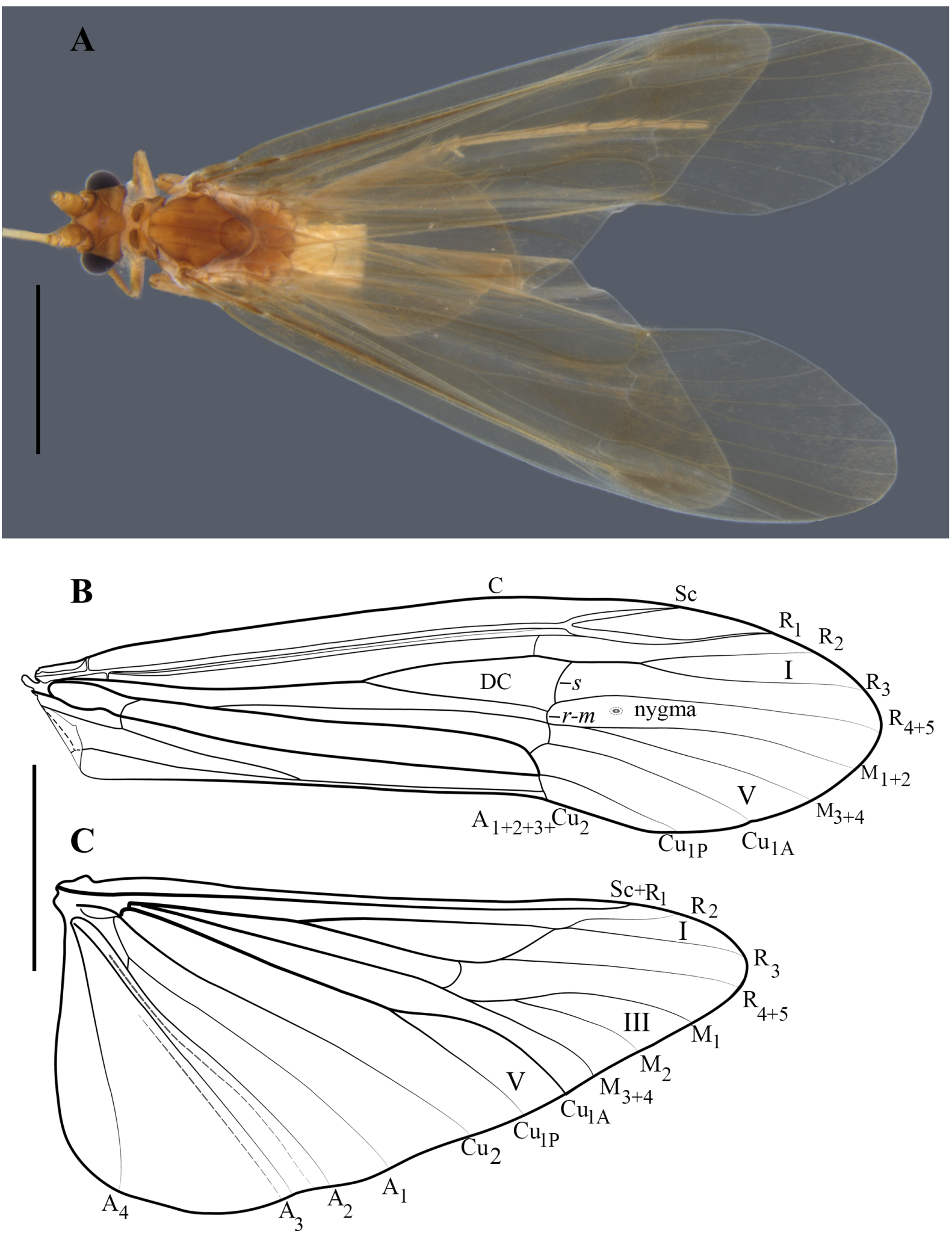

Fig. 1. Triplectides nessimiani Desidério \& Pes sp. nov., ô holotype (INPA-TRI 000014). A. Dorsal habitus. B. Venation of the forewing. C. Venation of the hind wing. Scale bars $=2 \mathrm{~mm}$. 


\section{A}

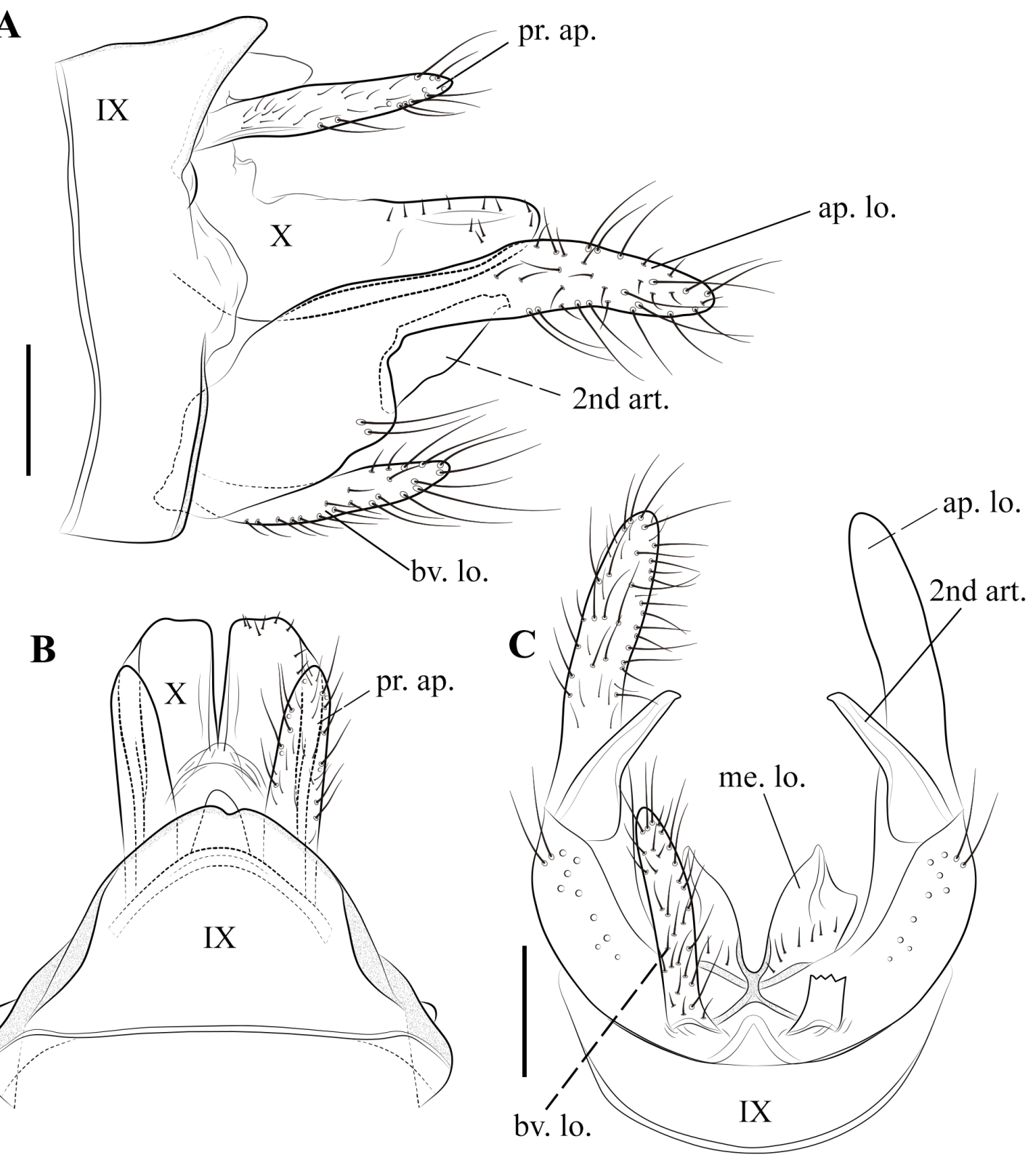

D

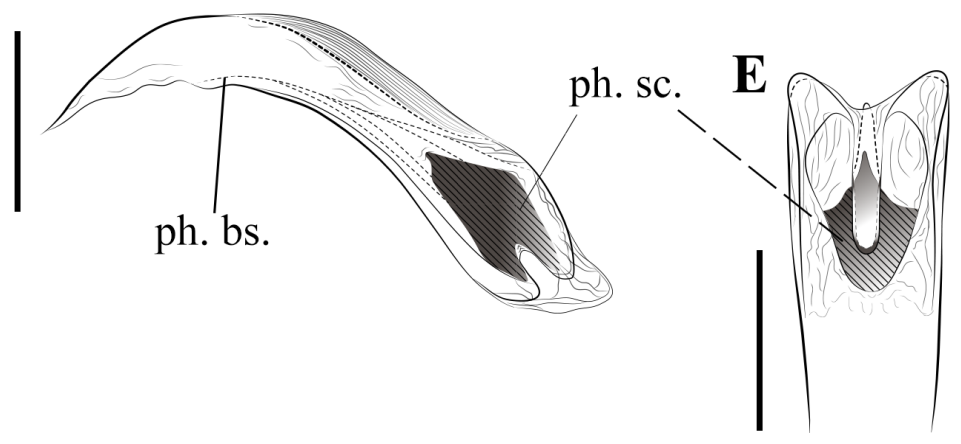

Fig. 2. Triplectides nessimiani Desidério \& Pes sp. nov., đ̊ genitalia, holotype (INPA-TRI 000014). A. Lateral view. B. Dorsal view. C. Ventral view. D. Phallic apparatus, lateral view. E. Phallotremal sclerite, dorsal view. Scale bars $=0.2 \mathrm{~mm}$. 


\section{Description}

Adult male (Figs 1A-C, 2A-E)

LENGTH OF FOREWING. 8.12-8.22 $\mathrm{mm}(\mathrm{n}=2)$.
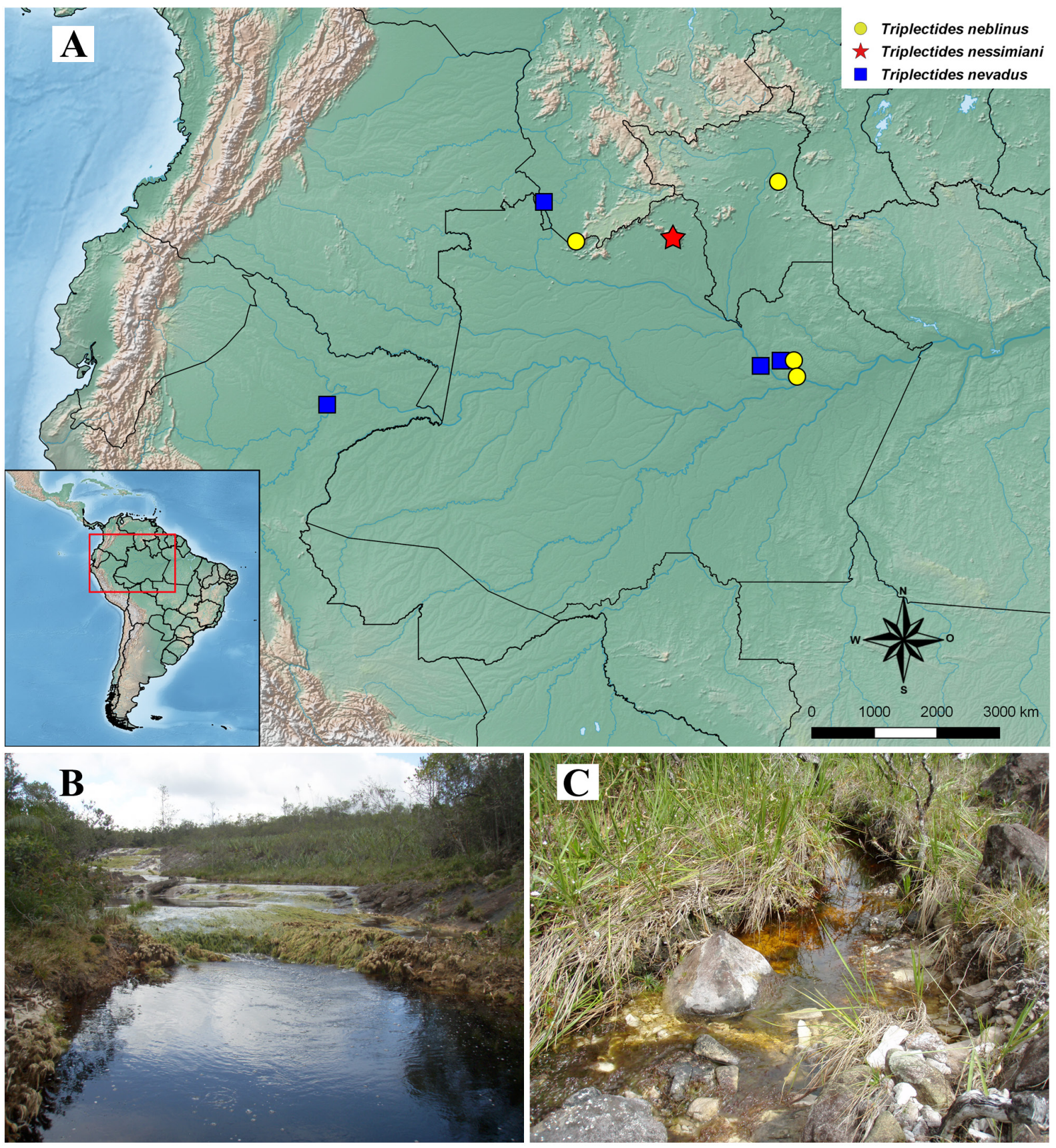

Fig. 3. Distribution of Triplectides species treated in this study and general view of the streams where Triplectides nessimiani Desidério \& Pes sp. nov. was collected. A. Distribution map of T. neblinus, T. nessimiani Desidério \& Pes sp. nov. and T. nevadus. B. Igarapé da Anta, Amazonas, Brazil, stream where T. nessimiani Desidério \& Pes sp. nov. holotype was collected. C. First order stream, Amazonas, Brazil, collection site of T. nessimiani Desidério \& Pes sp. nov. paratype. 
DESIDÉRIO G.R. et al., New species, records and a key of Triplectides from Brazil.

CoLOR. General color brown (in alcohol). Antennae with scape and pedicel golden-brown, flagellum pale-yellow (Fig. 1A) and palps brown. Forewing pale-brown (Fig. 1A), with small pale spots; with forks I and V present; discoidal cell about as broad as apical cells, nearly parallel-sided distally; cross vein $s$ long, curved; crossvein $r-m$ curved (Fig. 1B). Hind wing with forks I, III and V present; fork I with very short petiole (Fig. 1C). Legs pale-brown. Tibial spur formula 2:2:4.

Male genitalia (Fig. 2A-E). Segment IX, in lateral view, narrow, annular, with tergum IX produced posteriorly, anterior margin nearly straight, posterior margin produced medially (Fig. 2A); tergum IX with sclerotized posterior margin sharply rounded to slightly angulate and with small mesal notch (Fig. 2B), bearing rounded dorsomesal membranous process (absent in male paratype). Preanal appendages setose, about $3 / 4$ length of tergum X; in dorsal view, digitate, apices rounded (Fig. 2B). Tergum $\mathrm{X}$, in lateral view, with basal half less sclerotized than apical half, tall at base, narrowing apically (Fig. 2A), with ventral margin straight, apex rounded; in dorsal view, bearing short apical and lateral setae; apex obliquely truncated, with deep, V-shaped apicomesal incision extending anteriorly one-half the length of the segment (Fig. 2B). Inferior appendages long, surpassing tergum X, bearing long setae (Fig. 2A); each with $1^{\text {st }}$ article, in lateral view, enlarged basally, slightly constricted at mid-length (Fig. 2A); apicodorsal lobe digitate, long, extending beyond second article, with long setae (Fig. 2A, C); basoventral lobe digitate, long, apex rounded, bearing long setae (Fig. 2A, C); mesal lobe, in ventral view, shorter than basoventral lobe, subtriangular, bearing a row of 5-7 stout ventral setae basally, with two longitudinal striae, divided into long, blunt apical projection and slightly acute lateral projection, apex concave (Fig. 2C); $2^{\text {nd }}$ article short, slender, with pointed apex, directed apicomesad (Fig. 2C). Phallic apparatus elongate, complex; in lateral view, basal portion of phallobase subtriangular with ventral trough, middle portion curved and slender, apex with pair of wide, semimembranous flanges directed dorsolaterad; phallic membranes non-prominent, striate (Fig. 2D); phallotremal sclerite well developed, subpentagonal-shaped in dorsal view, with acute, thin median tip (Fig. 2E).

\section{Female and immature stages}

Unknown.

\section{Bionomics}

The males of $T$. nessimiani sp. nov. were collected in $1^{\text {st }}$ and $3^{\text {rd }}$ order streams with altitudes ranging from 1110 to $1130 \mathrm{~m}$ a.s.l. located in the Serra do Aracá mountain range, northern part of the Brazilian Amazon (Fig. 3A). The predominant vegetation is highland savanna (Fig. 3B), the water in the streams was black and acidic ( $\mathrm{pH} 4.3-4.5)$ with low conductivity $(10-20 \mu \mathrm{Scm}-1)$. At the sites where specimens were collected water temperatures of $21-22^{\circ} \mathrm{C}$ were recorded and the streams were $1-5 \mathrm{~m}$ wide, $0.30-3 \mathrm{~m}$ deep, with rocky bottoms characterized by boulders and slow-flowing water (Fig. 3BC).

Distribution (Fig. 3A)

Brazil (Amazonas state).

Triplectides neblinus Holzenthal, 1988

Fig. 3

Triplectides neblinus Holzenthal 1988: 199, figs 18-19 (type locality: Venezuela, Territorio Federal Amazonas, basecamp, $0^{\circ} 51^{\prime} \mathrm{N}, 66^{\circ} 10^{\prime} \mathrm{W}$, Cerro de la Neblina; NMNH; $\overbrace{}^{\circledR}$ ).

Triplectides neblinus - Holzenthal \& Calor 2017: 346 (catalog). 


\section{Material examined}

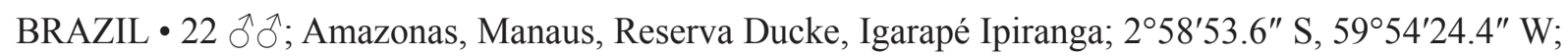
alt. 95 m; 7-19 Apr. 2017; G.R. Desidério and A.M.O. Pes leg.; Malaise trap; INPA-TRI $000016 \bullet 59$ §ో ठే; same collection data as for preceding; 19 Apr.-9 May 2017; G.R. Desidério, A.M.O. Pes and D. DePaula leg.; Malaise trap; INPA-TRI 000017 • 1 \%; Amazonas, Manaus, BR-174, km 56, ZF-2, sede (headquaraters), Ramal km 38, Igarapé de $1^{\circ}$ ordem (\#73); $2^{\circ} 35^{\prime} 50.9^{\prime \prime} \mathrm{S}, 60^{\circ} 12^{\prime} 54.9^{\prime \prime} \mathrm{W}$; alt. $49 \mathrm{~m}$; 9-12 Nov. 2008; U.G. Neiss, F.F. Sales, P.V. Cruz and F. Laurindo leg.; Suspended trap; INPA-TRI 000018

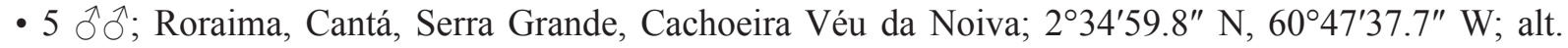
103 m; 19-21 Aug. 2019; N. Hamada, J.O. da Silva and R. Koroiva leg.; Malaise trap; INPA-TRI 000019.

Distribution (Fig. 3A)

Brazil (Amazonas and Roraima states) and Venezuela (Territorio Federal Amazonas).

Triplectides nevadus Holzenthal, 1988

Fig. 3

Triplectides nevadus Holzenthal 1988: 202, figs 22, 24 (type locality: Venezuela, Territorio Federal Amazonas, $2 \mathrm{~km}$ east of San Carlos de Río Negro; NMNH; đ̃; †).

Triplectides nevadus — Holzenthal \& Calor 2017: 347 (catalog).

\section{Material examined}

BRAZIL • 1 $\hat{\delta}^{\hat{2}}$; Amazonas, Manaus, BR-174, km 56, ZF-2, sede, Ramal km 38, $1^{\text {st }}$ order stream (\#73); 2³5'50.9" S, 60¹2'54.9" W; alt. 49 m; 9-12 Nov. 2008; U.G. Neiss, F.F. Sales, P.V. Cruz and F. Laurindo leg.; suspended trap; INPA-TRI 000020 - 1 ô; Amazonas, Novo Airão, AM-352, km 9, Sítio São Sebastião, Sr. Valdenor, 2 ${ }^{\text {nd }}$ order stream (\#15); 2 $2^{\circ} 42^{\prime} 04.5^{\prime \prime}$ S, 60 $55^{\circ} 23.4^{\prime \prime}$ W; alt. 50 m; 6 Apr. 2008; J.L. Nessimian, R. Querino, M. Pepinelli, C.A.S. Azevedo and U.G. Neiss leg.; Pennsylvania trap; INPA-TRI 000021.

\section{Distribution (Fig. 3A)}

Brazil (Amazonas state), Peru (Loreto) and Venezuela (Territorio Federal Amazonas).

\section{Key to males of Triplectides species with occurrence in Brazil (modified from Holzenthal 1988)}

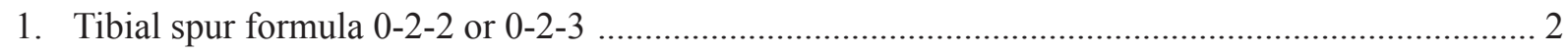

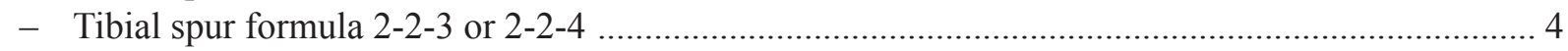

2. Preanal appendages very broad, rounded (see figs $18 \mathrm{a}-\mathrm{b}$ in Holzenthal 1988)

T. neblinus Holzenthal, 1988

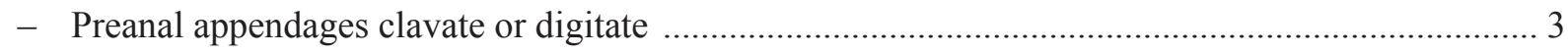

3. Mesal lobe of inferior appendage wrinkled in apical half (see fig. $3 \mathrm{c}$ in Desidério et al. 2017) T. maranhensis Desidério, Barcelos-Silva \& Pes, 2017

- Mesal lobe of inferior appendage non-wrinkled in apical half (see fig. 22c in Holzenthal 1988) T. nevadus Holzenthal, 1988

4. Tibial spur formula $2-2-3$

T. egleri Sattler, 1963

- Tibial spur formula 2-2-4 
DESIDÉRIO G.R. et al., New species, records and a key of Triplectides from Brazil.

5. Mesal lobe of inferior appendage short, subtriangular (see fig. 30c in Holzenthal 1988) ............... 6

- Mesal lobe of inferior appendage long, digitate (see fig. 9c in Holzenthal 1988) .......................... 7

6. Preanal appendages slender, with apices pointed; tergum $X$ with rounded apex (see fig. $30 \mathrm{~b}$ in Holzenthal 1988)

T. ultimus Holzenthal, 1988

- Preanal appendages digitate, with apices rounded; tergum X with truncate apex

T. nessimiani Desidério \& Pes sp. nov.

7. Mesal lobe of inferior appendage with apex acute, pointed, with small, lateral point (see fig. $15 \mathrm{c}$ in Holzenthal 1988)

T. misionensis Holzenthal, 1988

- Mesal lobe of inferior appendage with apex obtuse, rounded, without lateral point 8

8. Apex of mesal lobe of inferior appendage clearly capitate (see fig. 20c in Holzenthal 1988) T. neotropicus Holzenthal, 1988

- Apex of mesal lobe of inferior appendage rounded, not capitate 9

9. Hind wing fork I sessile or with very short petiole (see fig. 11b in Holzenthal 1988)

T. gracilis (Burmeister, 1839)

- Hind wing fork I with distinct petiole (see fig. 1 b in Dumas \& Nessimian 2010)

10. Tergum $X$ with subtruncate apex and apicomesal excision extending anteriorly at half-length of segment (see fig. 2 in Henriques-Oliveira \& Dumas 2015)

T. cipo Henriques-Oliveira \& Dumas, 2015

- Tergum X with rounded apex and apicomesal excision extending anteriorly to less than half length of segment (see fig. 3 in Dumas \& Nessimian 2010)

T. itatiaia Dumas \& Nessimian, 2010

\section{Discussion}

Until now, the diversity of Triplectides in Brazil is concentrated in the Southeast region with six species (Triplectides cipo, T. gracilis, T. itatiaia, T. misionensis, T. neotropicus and T. ultimus), followed by the Northeast (T. maranhensis and T. gracilis) and South (T. gracilis and T. misionensis) regions, both with two species registered. Only one species of Triplectides has been recorded from the North region so far, T. egleri (Santos et al. 2019), but with the new species described here, T. nessimiani sp. nov., and the new records of T. neblinus and T. nevadus, the number of Triplectides species reported from the North Region is increased to four, bringing the total number of species of the genus for Brazil to eleven (Table 1). However, the Midwest region is the only one that still has no recorded Triplectides species (Santos et al. 2019).

Triplectides neblinus was previously known only from its type locality at the Cerro de la Neblina base camp at $140 \mathrm{~m}$ a.s.l. (Holzenthal 1988), a mountainous region located in the southern portion of Venezuela at the border with Brazil. Here the distribution range of this species is extended to Amazonas and Roraima states, representing the first record for Brazil, at a distance of about $800 \mathrm{~km}$ from the type locality.

Triplectides nevadus was previously known from large rivers in Venezuela (Rio Negro) and Peru (Rio Nanay) (Holzenthal 1988). In this study the species was collected in two small streams in the Amazonas State, being reported for the first time for Brazil.

Although this study improves our knowledge of the Triplectides species that occur in Brazil, it does not represent the actual diversity of the genus. This is due to the scarcity of studies, particularly in neighboring states that share the Amazon biome, such as Acre, Amapá and Rondônia, and in the states of the Midwest 
Table 1. Distribution of Triplectides species recorded from Brazil. Abbreviations for Brazilian states: $\mathrm{AM}=$ Amazonas; $\mathrm{BA}=$ Bahia; ES = Espírito Santo; $\mathrm{MA}=$ Maranhão; $\mathrm{MG}=$ Minas Gerais; PA = Pará; $\mathrm{PR}=$ Paraná; $\mathrm{RJ}=$ Rio de Janeiro; $\mathrm{RR}=$ Roraima; $\mathrm{SC}=$ Santa Catarina; $\mathrm{SP}=$ São Paulo.

\begin{tabular}{ll}
\hline Species & Regions (States) \\
\hline T. cipo Henriques-Oliveira \& Dumas, 2015 & Southeast (MG) \\
T. egleri Sattler, 1963 & North (AM, PA) \\
T. gracilis (Burmeister, 1839) & Northeast (BA); Southeast (ES, \\
T. itatiaia Dumas \& Nessimian, 2010 & MG, RJ, SP); South (PR, SC) \\
T. maranhensis Desidério, Barcelos-Silva \& Pes, 2017 & Southeast (RJ) \\
T. misionensis Holzenthal, 1988 & Northeast (MA) \\
T. neblinus Holzenthal, 1988 & Southeast (MG, RJ, SP); South \\
T. neotropicus Holzenthal, 1988 & (PR, SC) \\
T. nessimiani Desidério \& Pes sp. nov. & North (AM, RR) \\
T. nevadus Holzenthal, 1988 & Southeast (MG, RJ, SP) \\
T. ultimus Holzenthal, 1988 & North (AM) \\
& North (AM) \\
\hline
\end{tabular}

region (Distrito Federal, Goiás, Mato Grosso and Mato Grosso do Sul). Thus, these data highlight the need for more taxonomic studies focused on Triplectides in the Brazilian Amazon specifically and in Central Brazil, where it is highly probable that any specimens of this genus discovered in the future will be new to science or represent new distributional records for these regions.

\section{Acknowledgments}

We thank all of the members of the Serra do Aracá expedition in July-August 2009 for their valuable assistance in the fieldwork. Financial support was provided by the PRONEX-CNPq-FAPEAM/INPA. Collections were made under SISBIO license no. 1369-2 and license 17/09 CEUC/SDS-Amazonas. We also thank the Invertebrate Collection of INPA for allowing use of photographic equipment. CNPq provided a doctoral fellowship for GRD (Process n. 141875/2018-6) and a research fellowship for NH (Process n. 307849/2014-7). AMP received post-doctoral fellowships from PDS/CNPq (Process n. 165223/2017-0) and PCI-DB (Process n. 301401/2019-5). We thank Philip M. Fearnside for revising this manuscript. We are grateful to the editor, Dr. Helen M. Barber-James, for the assistance and we highly appreciate the very useful suggestions of the two anonymous reviewers to improve the manuscript.

\section{References}

Blahnik R.J. \& Holzenthal R.W. 2004. Collection and curation of Trichoptera, with an emphasis on pinned material. Nectopsyche, Neotropical Trichoptera Newsletter 1: 8-20.

Desidério G.R., Barcelos-Silva P., Souza W.R.M., Pes A.M. \& Azevedo C.A.S. 2017. Caddisflies (Insecta: Trichoptera) from Maranhão State, Northeast Region, Brazil: A new species, checklist, and new geographical records. Zootaxa 4221 (2): 151-171. https://doi.org/10.11646/zootaxa.4221.2.1

Dumas L.L. \& Nessimian J.L. 2010. A new long-horned caddisfly in the genus Triplectides Kolenati (Trichoptera: Leptoceridae) from the Itatiaia Massif, Southeastern Brazil. Neotropical Entomology 39: 949-951. https://doi.org/10.1590/S1519-566X2010000600016 
DESIDÉRIO G.R. et al., New species, records and a key of Triplectides from Brazil.

Frost S.W. 1957. The Pennsylvania insect light trap. Journal of Economic Entomology 9: 52-172.

Gressit J.L. \& Gressit M.K. 1962. An improved Malaise trap. Pacific Insects 4: 87-90.

Henriques-Oliveira A.L. \& Dumas L.L. 2015. Two new species of Triplectides (Trichoptera: Leptoceridae) from South America. Zoologia 32: 66-70. https://doi.org/10.1590/S1984-46702015000100010

Holzenthal R.W. 1988. Systematics of Neotropical Triplectides (Trichoptera: Leptoceridae). Annals of the Entomological Society of America 81: 187-208. https://doi.org/10.1093/aesa/81.2.187

Holzenthal R.W. \& Calor A.R. 2017. Catalog of the Neotropical Trichoptera (Caddisflies). ZooKeys 654: 1-566. https://doi.org/10.3897/zookeys.654.9516

Malm T. \& Johanson K.A. 2008. Description of eleven new Triplectides species (Trichoptera: Leptoceridae) from New Caledonia. Zootaxa 1816: 1-34. https://doi.org/10.11646/zootaxa.1816.1.1

Malm T. \& Johanson K.A. 2011. A new classification of the long-horned caddisflies (Trichoptera: Leptoceridae) based on molecular data. BMC Evolutionary Biology 11 (10): 1-17.

https://doi.org/10.1186/1471-2148-11-10

Morse J.C. 2018. Trichoptera World Checklist. Available from https://entweb.sites.clemson.edu/database/trichopt/ [accessed 24 Dec. 2018].

Morse J.C. \& Neboiss A. 1982. Triplectides of Australia (Insecta: Trichoptera: Leptoceridae). Memoirs of the National Museum Victoria 43: 61-98.

Rafael J.A. \& Gorayeb I.S. 1982. Tabanidae (Diptera) da Amazônia, I - Uma nova armadilha suspensa e primeiros registros de mutucas de copas de árvores. Acta Amazonica 12: 232-236.

Santos A.P.M., Dumas L.L., Pes A.M.O, Calor A.R., Souza W.R.M., Henriques-Oliveira A.L. \& Camargos L.M. 2019. Trichoptera. In: Catálogo Taxonômico da Fauna do Brasil. Programa das Nações Unidas do Desenvolvimento (PNUD), Brasília, DF, Brazil. Available at:

http://fauna.jbrj.gov.br/fauna/faunadobrasil/278 [accessed 28 Feb. 2019].

Manuscript received: 10 October 2019

Manuscript accepted: 3 April 2020

Published on: 1 July 2020

Topic editor: Nesrine Akkari

Section editor: Helen M. Barber-James

Desk editor: Marianne Salaün

Printed versions of all papers are also deposited in the libraries of the institutes that are members of the EJT consortium: Muséum national d'Histoire naturelle, Paris, France; Botanic Garden Meise, Belgium; Royal Museum for Central Africa, Tervuren, Belgium; Royal Belgian Institute of Natural Sciences, Brussels, Belgium; Natural History Museum of Denmark, Copenhagen, Denmark; Naturalis Biodiversity Center, Leiden, the Netherlands; Museo Nacional de Ciencias Naturales-CSIC, Madrid, Spain; Real Jardín Botánico de Madrid CSIC, Spain; Zoological Research Museum Alexander Koenig, Bonn, Germany; National Museum, Prague, Czech Republic. 